\title{
Antiproliferative Effect of Ethanolic Extract Eugenia uniflora Lam. Leaves on T47D Cells
}

\author{
Nur Ismiyati ${ }^{*}$, Dyaningtyas Dewi Pamungkas Putri ${ }^{2}$, Siska Andrina Kusumastuti ${ }^{2}$, \\ Rifki Febriansyah ${ }^{3}$ \\ ${ }^{1}$ Department of Pharmacy, Politeknik Kesehatan Bhakti Setya Indonesia, Yogyakarta, Indonesia \\ ${ }^{2}$ Cancer Chemoprevention Research Center Faculty of Pharmacy, Universitas Gadjah Mada, Jalan Sekip Utara \\ 55281, Yogyakarta, Indonesia, (Phone. 02746492662 Fax. 543120) http://ccrc.farmasi.ugm.ac.id \\ ${ }^{3}$ Universitas Muhammadiyah Yogyakarta, Yogyakarta, Indonesia
}

\begin{abstract}
Eugenia uniflora Lam. is one of herbal products developed for anticancer. The aim of the present study was to identify the antiproliferative effect of ethanolic extract of Eugenia Uniflora Lam. leaves (EEU) on breast cancer cell line T47D. This Research was initiated by extracting the active contents of Eugenia uniflora Lam. leaves by maceration with ethanol $96 \%$. The extract was then analyzed by thin layer chromatography (TLC). Cytotoxic assay of EEU was carried out by using MTT assay. Apoptosis phenomenon was observed with double staining using acridine orange-ethidium bromide. EEU showed cytotoxic effect on T47D cells with $\mathrm{IC}_{50}$ value of $65 \mu \mathrm{g} / \mathrm{ml}$. Moreover, EEU $50 \mu \mathrm{g} / \mathrm{ml}$ and $100 \mu \mathrm{g} / \mathrm{ml}$ induced apoptosis. TLC examination showed that EEU used in this study contain phenolic, flavonoid, and saponin compounds which were suggested to be responsible for antiproliferative effect. Further molecular mechanism underlying EEU antiproliferative effect needs to be done.
\end{abstract}

Keywords: Eugenia uniflora Lam., T47D cells, antiproliferative, apoptosis

\section{INTRODUCTION}

Breast cancer shows the highest cancer case in women worldwide. Breast cancer is the $2^{\text {nd }}$ most frequently cancer in Indonesian woman after cervical cancer (Tjindarbumi and Mangunkusumo, 2002). There are several therapies toward breast cancer, such as biopsy, mastectomy, radiation, hyperthermia, also chemotherapy. However, most of cytostatic agent is not specifically targeted cancer cells. These compounds could be harmful for normal cells which proliferate extensively, such as bone marrow, hair, gastrointestinal, and reproductive cells (Raharja and Tjay, 2002). Thus, research focus to observe drug molecule which is safe, effective, and selective.

National Cancer Institute (NCI) reported that some effective anticancer agents come from nature. One of the potential plant is Eugenia uniflora L.. The leaf and branch of $E$. uniflora L. contain flavonoid, saponin, and tannin (Hutapea, 1994). Flavonoid is a natural compound exhibited anticancer activity (Harborne, 1987). Flavonoid contained in leaf extract of Eugenia uniflora L. are myricetin, myricitrin, quercetin, gallocatechin, and quercitrin (Scameda-Hirschmann et al., 1987). Whereas, other compounds such as gallocatechin, oenothein B, eugeniflorins $\mathrm{D}(1)$ and $\mathrm{D}(2)$ could inhibit DNA polymerase of Epstein-Barr Virus (EBV) which play role in replication of EBV (Lee et al., 2000). Ethyl acetate fraction and chloroform extract also showed cytotoxic effect on HeLa cells (Handayani, 2006). This study was aimed to observe antiproliferative and induction of apoptosis caused by ethanolic extract of $E$. uniflora L. leaves (EEU) on T47D cells.

\section{MATERIALS AND METHODS}

\section{Extraction}

Eugenia uniflora L. leaves were collected and determined in B2P2TO2T (Balai Besar Penelitian dan Pengembangan Tanaman Obat dan Obat Tradisional), Tawangmangu, Central Java. Sample was then dried and powdered. The powder macerated with ethanol $96 \%$ for $3 \times 24$ hours. Filtrate was concentrated using rotary evaporator at $60^{\circ} \mathrm{C}$.

\footnotetext{
*Corresponding author e-mail: nur_is@yahoo.com
} 


\section{Cells Culture}

Human breast cancer T47D culture cells culture were a collection of Cancer Chemoprevention Research Center (CCRC), Universitas Gadjah Mada. The cell was a gift from Prof. Kawaichi, Nara Institute of Science and Technology (NAIST), Japan. Cells were cultured in culture medium DMEM (Gibco) supplemented with $10 \%$ Fetal Bovine Serum (Sigma)

\section{Cytotoxic Assay}

Cytotoxic assay was done using MTT (3[4,5-dimethylthiazol-2-yl]-2,5 diphenyl tetrazolium bromide) (Mosmann, 1983). Cells in $80 \%$ confluent were harvested and counted, then diluted with complete culture medium. The cells were then transferred into a 96-well plate with a total of $1 \times 10^{4}$ cells/well followed by 24 hours incubation. After that, the sample was added to the wells at various concentrations with co-solvent DMSO and incubated at $37^{\circ} \mathrm{C}$ in a $5 \% \mathrm{CO}_{2}$ incubator for 24 hours. At the ends of incubation, $100 \mu \mathrm{L}$ MTT reagent with concentration of $0.5 \mathrm{mg} / \mathrm{ml}$ in DMEM was added into each well. The plate was then incubated at $37^{\circ} \mathrm{C}$ for 6 hours until formazan was formed. Once formazan was formed, stopper Isopropanol- $\mathrm{HCl} 4 \mathrm{~N}$ was added. Plate was then wrapped with paper or alumunium foil and incubated in dark condition overnight. Absorbance was determined with an ELISA reader at $\lambda 550 \mathrm{~nm}$.

\section{Proliferation Assay}

Proliferation assay was done using MTT assay. Cells were seeded with a total of 1 x $10^{4}$ cells/well and incubated for 24 hours. After that, the sample was added to the wells in $\mathrm{IC}_{50}$ concentration and incubated for various time $(0,24,48$, and 72 hours). MTT assay then was conducted as described in cytotoxic assay methods.

\section{Apoptosis Observation}

Apoptosis was observed with double staining method using acrydine orangeethidium bromide. Cells $\left(5 \times 10^{4}\right)$ were seeded at coverslip in 24-wellplate. Cells were then incubated with sample $(50 \mu \mathrm{g} / \mathrm{ml}$ and 100 $\mu \mathrm{g} / \mathrm{ml}$ ) for 24 hours. After incubation, medium was removed and was added with $10 \mu \mathrm{l}$ acridine orange-ethidium bromide. Cells were observed under fluorescent microscope with 100x magnification.

\section{Data Analysis}

Cytotoxic assay. Linear regression between concentration and \% cell viability giving the equation $\mathrm{y}=\mathrm{Bx}+\mathrm{A}$ which were used to calculate $\mathrm{IC}_{50}$ value, that is the concentration inhibiting 50\% of cell growth.

Proliferation assay. Paired sample t-test was used to observe significance difference between control and treated cells' absorbance. Linier regression between incubation time vs cells absorbance was made and the slope was analyzed. Slope in the graph indicating cell cycle arrest phenomenon.

Apoptosis observation. Cells' morphology was observed under fluorescence microscope. Viable cells were in normal shape and green color, while death cells caused by necrosis were orange. Early apoptotic cells were green but brighter in the middle compared to viable cells. Late apoptotic cells were orange until red and formed apoptotic bodies (McGahon et al., 1995).

\section{RESULTS AND DISCUSSION}

\section{Cytotoxic Effect of EEU on T47D Cells}

Cytotoxic assay was carried out by using MTT assay. Absorbance measured was linier with cells viability. Cytotoxic assay was done using EEU concentration 25, 50, 100, 250, and $500 \mu \mathrm{g} / \mathrm{ml}$. After the treatment, cells were observed under light microscope. EEU altered cells morphology. Increase of EEU concentration caused more cells undergoing morphological alteration, which was indicated by cells becoming rounded form and detached from well (Fig.1(A-D)). Overall, EEU showed cytotoxic activity in dose dependent phenomenon with $\mathrm{IC}_{50}$ value of $65 \mu \mathrm{g} / \mathrm{ml}$ (Fig.1(E)). 


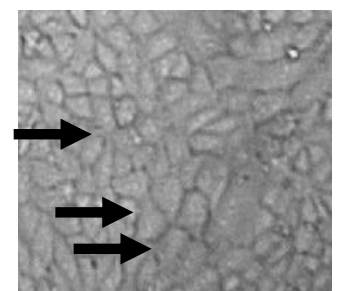

(A)

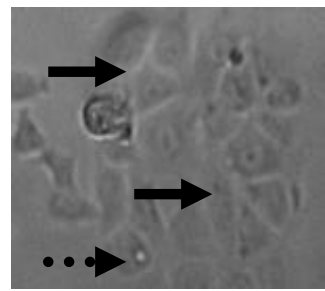

(B)

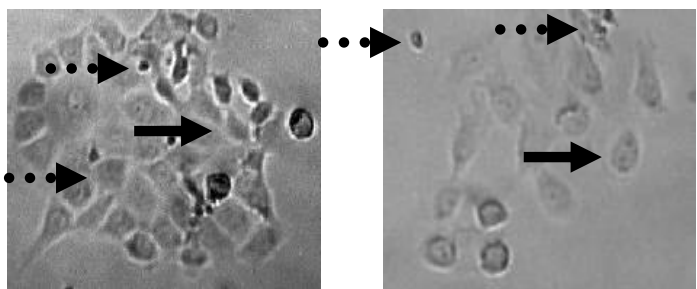

(C)

(D)

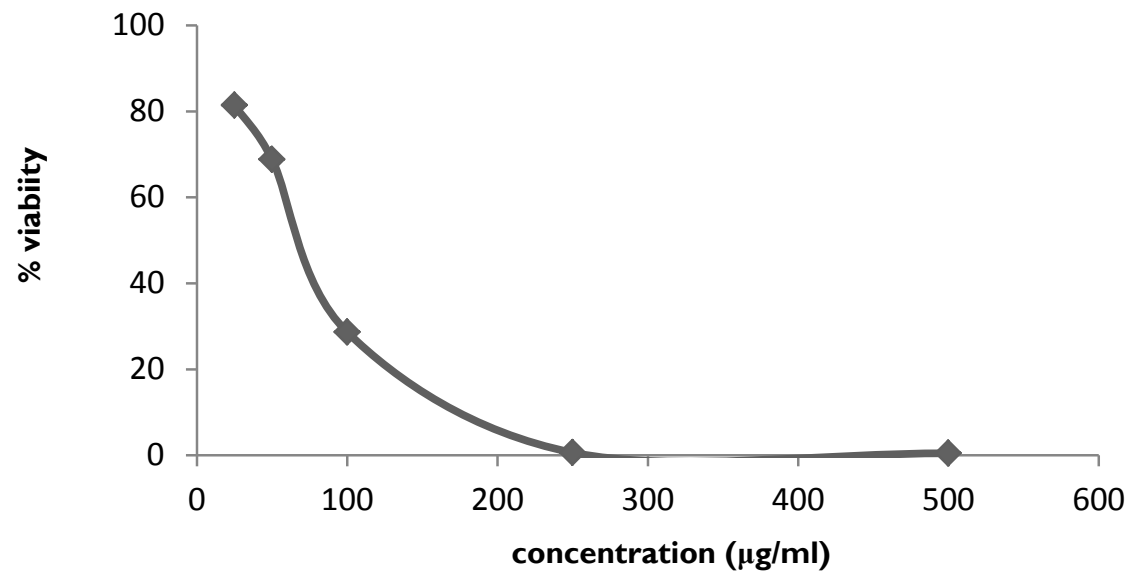

(E)

Figure I. Cytotoxic Effect of EEU on T47D cells. T47D cells ( $1 \times 10^{4}$ cells/well) were seeded in 96-well plate and treated with EEU 25, 50, 100, 250, and $500 \mu \mathrm{g} / \mathrm{ml}$. Cell treated with EEU (A) none (control); (B) $25 \mu \mathrm{g} / \mathrm{ml}$; (C) $100 \mu \mathrm{g} / \mathrm{ml}$; and (D) $500 \mu \mathrm{g} / \mathrm{ml}$, observed under light microscope with 400x magnification. Arrows $(\rightarrow)$ ) indicationg viable cells and dotted arrows $(\bullet \rightarrow)$ indicating death cells. Cells viability was then measured by using MTT assay as described in the methods and EEU showed cytotoxic effect on T47D cells in dose dependent phenomenon as shown in graph (E).

\section{Effect of EEU on T47D Cells Proliferation}

Cell proliferation was also measured by using MTT assay. The absorbance at certain incubation times was measured and correlated with cell viability at these times. Cells were treated with EEU 25, 50, and 75 $\mu \mathrm{g} / \mathrm{ml}$. Proliferation kinetics showed in graph between incubation time versus cell absorbance (Fig.2). 


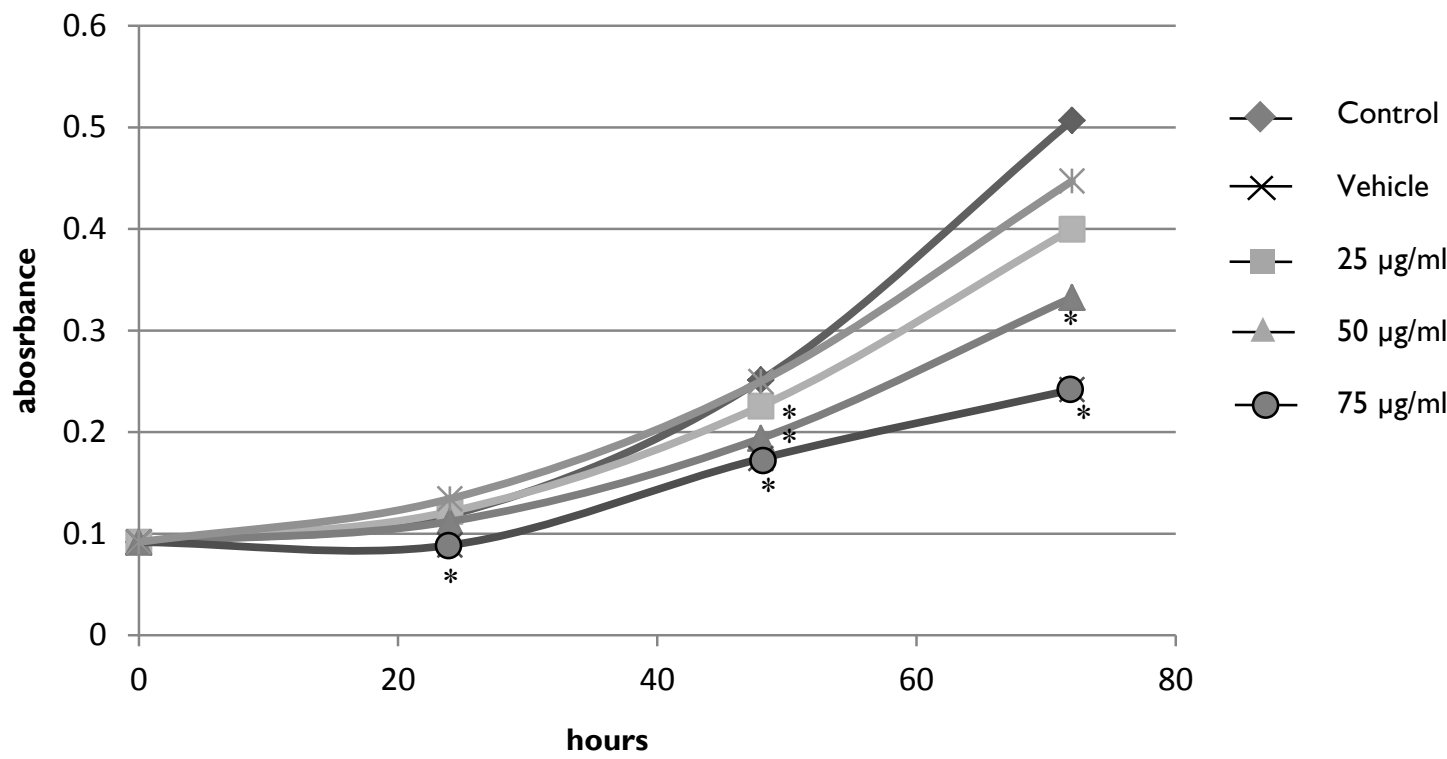

Figure 2. Effect of EEU on T47D Cells Proliferation. T47D cells ( I $10^{4}$ cells/well) were seeded in 96well plate and treated with EEU 25,50 , and $75 \mu \mathrm{g} / \mathrm{ml}$. Cells viability was determined by using MTT assay and the cells absorbance were measured at 24, 48, and 72 hour of incubation. Absorbance then were plotted in the graph and analyzed statistically by using paired sample t-test $(p<0.05)$. (*) indicating significant difference between treated cells and control cells at the same time of incubation.

Data obtained were then analyzed by using paired sample t-test with $\mathrm{p}<0.05$. EEU 25 $\mu \mathrm{g} / \mathrm{ml}$ decreased T47D cells proliferation significantly only at 48 hours of incubation; EEU $50 \mu \mathrm{g} / \mathrm{ml}$ decreased cells proliferation significantly at 48 and 72 hours of incubation; while EEU $75 \mu \mathrm{g} / \mathrm{ml}$ decreased cells proliferation at all incubation time $(24,48$, and 72 hours). Inhibition of cells proliferation also could be observed from the slope value of linier regression between times of incubation versus absorbance (Table I). The higher concentration of EEU, the smaller the slope obtained. EEU 75 $\mu \mathrm{g} / \mathrm{ml}$ gave the smallest slope, meaning the highest cells proliferation inhibition. Based on the data, EEU inhibited cells proliferation in dose and time dependent manner. The decrease of cells viability could be attributed with cell cycle arrest, apoptosis, necrosis, or combination of them.

Tabel I. Proliferation kinetics of T47D cells at $0-72$ hours of incubation.

\begin{tabular}{llcc}
\hline \multicolumn{1}{c}{ Groups } & Linier Regression & Slope & Linearity $\left(\mathbf{R}^{2}\right)$ \\
\hline Control & $\mathrm{y}=0,008 \mathrm{Ix}-0,0964$ & $0,008 \mathrm{1}$ & 0,9678 \\
EEU $25 \mu \mathrm{g} / \mathrm{ml}$ & $\mathrm{y}=0,0058 \mathrm{x}-0,029 \mathrm{I}$ & 0,0058 & $0,979 \mathrm{I}$ \\
EEU $50 \mu \mathrm{g} / \mathrm{ml}$ & $\mathrm{y}=0,0046 \mathrm{x}-0,0076$ & 0,0046 & 0,9784 \\
EEU $75 \mu \mathrm{g} / \mathrm{ml}$ & $\mathrm{y}=0,0032 \mathrm{x}+0,015 \mathrm{I}$ & 0,0032 & 0,9957 \\
Vehicle & $\mathrm{y}=0,0065 \mathrm{x}-0,0356$ & 0,0065 & 0,9778 \\
\hline
\end{tabular}

\section{Effect of EEU on T47D Cells Apoptosis}

Double staining using acridine orangeethidium bromide was done to evaluate the effect of EEU on apoptosis. EEU $50 \mu \mathrm{g} / \mathrm{ml}$ caused cells undergoing green with lighter nuclear (Fig.3). This phenomenon indicated early apoptotic cells (McGahon et al., 1995). Moreover, EEU $100 \mu \mathrm{g} / \mathrm{ml}$ caused a lot of cells became orange with fragmented DNA, which indicating the late apoptotic cells. 


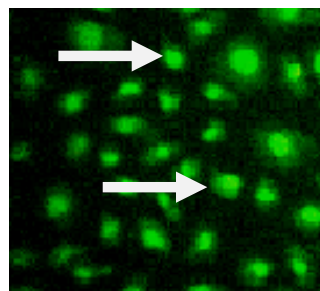

(A)

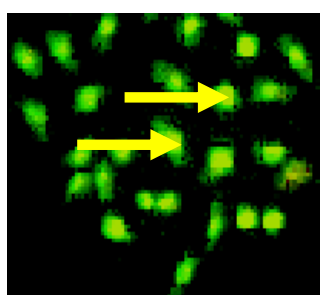

(B)

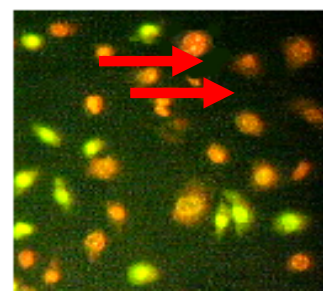

(C)

Figure 3. Effect of EEU on T47D Cells Apoptosis. T47D cells $\left(5 \times 10^{4}\right)$ were seeded at coverslip in 24wellplate, treated with EEU, and stained with acridine orange-ethidium bromide as described in methods. Cells were then observed under fluorescent microscope with 100x magnification. Cells treated with (A) none (control), (B) EEU $50 \mu \mathrm{g} / \mathrm{ml}$, and (C) EEU 100

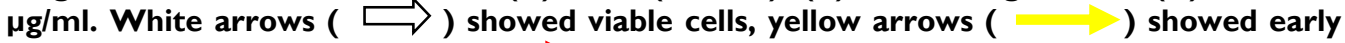
apoptotic cells, and red arrows $(\longrightarrow$ ) showed late apoptotic cells.

Induction of apoptosis occurred on T47D cells used in this study may happen through p53-independent pathway, such as via transmembrane death receptor. Gallic acid is a polyphenolic compound which could induce apoptosis through that pathway (Nam et al., 2001). Apoptosis occurred as a result of CD95 or Fas signal transduction (Taraphdar et al., 2001). Fas is a member of TNF receptor which bind to FasL, leading to trimerization of Fas and induce several signal transduction (Kampa et al., 2003). FADD then binds to trimer of Fas and activates caspase- 8 . Activated caspase- 8 would activate caspae-3, an apoptosis effector (Yau, 2004). Flavonoid quercetin and myricetin also induced apoptosis through the release of cytochrome c (Taraphdar et al., 2001), leading to activation of caspase-9 and caspase-3 (King, 2000).

Overall, this study showed that EEU performed cytotoxic effect on T47D breast cancer cells, inhibited T47D cells proliferation, as well as induced apoptosis. Further research need to be conduct is to observe molecular mechanism of EEU and its selectivity on normal cells.

\section{ACKNOWLEDGEMENT}

We acknowledge Cancer Chemopreventive Research Center, Faculty of Pharmacy, Universitas Gadjah Mada who funded this research.

\section{REFERENCES}

Handayani, S., 2006, Efek Sitotoksik Ekstrak Kloroform, Etil Asetat, dan Etanol Daun Dewandaru (Eugenia uniflora
Linn.) terhadap Sel Hela, Skripsi, Fakultas Farmasi Universitas Muhamadiyah Surakarta, Surakarta.

Harborne, J.B., 1987, Metode Fitokimia, Penuntun Cara Modern Menganalisis Tumbuhan, Penerbit ITB, Bandung.

Hutapea, J.R., 1994, Inventaris Tanaman Obat Indonesia, Jilid III, Departemen Kesehatan RI dan Badan Penelitian dan Pengembangan Kesehatan, 29-30.

Kampa, M., Alexaki, VI, Notas, G., Nifli, A.P., Nistikaki, A., Hatzoglou, A., Bakogeorgou, E., Kouimtzoglou, E., Blekas, G., Boskou, D., Gravanis, A. and Castanas, E., 2003, Antiproliferative and Antiapoptotic Effects of Selective Phenolic Acids on T47D Human Breast Cancer Cells: Potential Mechanism of Action, Breast Cancer Res., 6, 63-74.

King, R.J.B., 2000, Cancer Biology, $2^{\text {nd }}$ Ed., Pearson Eduation Limited, London.

Lee, M., Chiou, J., Yen, K. and Yang, L., 2000, EBV DNA polymerase Inhibition of tannins from Eugenia uniflora, Cancer Letters, $154,|3|-\mid 36$.

McGahon, A.J., Martin, S.J., Bissonnette, R.P., Mahboubi, M., Shi, Y., Mogil, R.J., Nishioka, W.K. and Green, D.R., 1995, The End of the (Cell) Line: Methods for the Study of Apoptosis in Vitro, in: Schwartz, L.M., Osborn, B.A., Cell Death, Academic Press, San Diego.

Nam, S., David, M., Smith, and Dou, Ping, Q., 200I, Tannic Acid Potently Inhibits Tumor Cell Proteasome Activity, Increases p27 and Bax Expression, and Induces $G_{1}$ Arrest and Apoptosis, 
Cancer Eidemiology, Biomarkers and Prevention, 10, 1083-1088.

Rahardja, K. and Tjay, T.H., 2002, Obat-Obat Penting Khasiat, Penggunaan, dan EfekEfek Sampingnya, Edisi 5, P.T. Elex Media Komputindo Kelompok Gramedia, Jakarta.

Schmeda-Hirschmann, G., Theoduloz, C., Franco, L., Ferro, E. and Rojas De Arias, A., 1987, Preliminary pharmacological studies on Eugenia uniflora leaves: xanthine oxidase inhibitory activity, Journal of Ethnopharmacology, 2I, I83-186.
Taraphdar, A.K., Roy, M. and Bhattacharya, R.K., 200I, Natural products as inducers of apoptosis: implication for cancer theraphy and prevention, Curr. Sci., 80, I387-1396.

Tjindarbumi, D. and Mangunkusumo, R., 200I, Cancer in Indonesia, Present and Future, Jpn. J. Clin. Oncol., 32 (Supplement I), SI7-S2I.

Wagner, H. and Bladt, S., 1996, Plant Drug Analysis The Thin Layer Chromatography Atlas, 2nd edition, Springer Verlag, Berlin. 